\title{
CHARLES WHITNEY GILMORE AND THE WEST OF IMAGINATION
}

BREITHAUPT, Brent H., Geological Museum, University of Wyoming, Laramie, WY 82071-3006, U.S.A.

Charles Whitney Gilmore was born on March 11, 1874 in Pavilion, New York. At age 6, his interests in paleontology and museology were entrenched after a visit to Ward's Natural Science Establishment in Rochester. Immediately after this trip, collections of fossil shells, rocks, birds' eggs and insects appeared in the Gilmore household. In 1882 the family moved to Howell, Michigan where Charles graduated from high school.

Gilmore's fondness of outdoor activities, enthusiasm for the natural sciences, adventuresome spirit, thirst for knowledge, and lust for independence spurred him west to the Rocky Mountains. A visit to the frontier town of Laramie in April of 1896 led him to enroll at the University of Wyoming. During this spring visit he traveled onto the windswept prairie of the Laramie Plains with the versatile Wyoming geologist Wilbur Clinton Knight. Gilmore was shown an impressive array of immense fossil reptile bones in the ground and determined that these were the kinds of specimens that he would like to study. Soon after beginning his studies, he accepted the position as Student Assistant to Knight and devoted all of his spare time to the collection and preparation of fossils. While at the University of Wyoming, he resolved to make the study and collection of vertebrate fossils, in particular dinosaurs, his life's work.

Under the tutelage of Knight and his premier assistant William Harlow Reed (the discoverer of Como Bluff and a world renowned fossil collector), Gilmore helped amass one of the best collections of American Jurassic vertebrate fossils in the world by the turn of the century. Knight and Reed strove to use the abundant paleontological resources of southeastern Wyoming to establish a museum of world renown. Between 1896 and 1899 almost 10,000 specimens, including over 70 tons of Jurassic plant (e.g., cycads) and giant reptile (e.g., dinosaurs, ichthyosaurs, plesiosaurs) fossils were collected. In 1897 alone, over 5 tons of ancient reptile remains (including many new taxa) were brought back to Laramie.

Gilmore received his Bachelor of Science degree from the University of Wyoming in 1901. Later that same year, his experiences in the West garnered him the appointment of Collector and Preparator of Fossils at the Carnegie Museum in Pittsburgh, Pennsylvania, where he made significant contributions to vertebrate paleontology. In 1903 he began a long and faithful career at the United States National Museum in Washington D.C. With a tenure spanning four decades in the Division of Vertebrate Paleontology, Gilmore held the positions of Preparator, Custodian, Assistant Curator, Associate Curator, and Curator. He was a well-rounded paleontologist with a devotion to field and laboratory work. His contributions to the understanding of fossil reptiles of all sizes are well known. While at the National Museum, he engaged in 16 major expeditions (primarily in the West) and published over 170 papers. He remained at this institution until his death in 1945. 